\title{
Organic matter mineralization in intertidal sediments along an estuarine gradient
}

\author{
Jack J. Middelburg*, Gerard Klaver**, Joop Nieuwenhuize, Annette Wielemaker, \\ Wim de Haas, Tom Vlug, Jaco F. W. A. van der Nat
}

Netherlands Institute of Ecology, Vierstraat 28, 4401 EA Yerseke, The Netherlands

\begin{abstract}
A seasonal study of organic matter mineralization rates was made at 8 intertidal stations in the Westerschelde Estuary (The Netherlands). Organic matter mineralization rates, based on the gaseous emission of carbon dioxide and methane, showed significant dynamic temporal and spatial variability at various scales. Annual rates of organic matter mineralization varied from 8 to about $339 \mathrm{~mol} \mathrm{C} \mathrm{m} \mathrm{yr}^{-2}$. The temperature dependence of organic matter degradation was described using an Arrhenius-type equation. Activation energies ranged from 54 to $125 \mathrm{~kJ} \mathrm{~mol}^{-1}$ and correlated negatively with depth-integrated rates of mineralization. Spatial differences in mineralization were mainly due to differences in the lability of the organic matter, since the quantity of organic matter was similar between stations on an areal or volume basis. Average first-order decomposition rate constants ranged from 0.2 to $7 \mathrm{yr}^{-1}$ and decreased towards the seaward end of the estuary due to ageing of riverinederived material. Intertidal sediments were estimated to account for about $25^{\prime \prime}$ of of the total carbon retention in the Westerschelde estuary.
\end{abstract}

KEY WORDS: Organic matter - Mineralization Intertidal sediments - Estuary - Methane Carbon budget Activation energy

\section{INTRODUCTION}

Estuaries lie at the interface between freshwater and marine systems forming the transition between these 2 environments (Martens \& Goldhaber 1978). They are highly variable and dynamic systems with large seasonal and spatial gradients (Heip et al. 1995). In order to evaluate the importance of benthic mineralization in biogeochemical cycles of estuarine ecosytems, it is therefore mandatory to consider temporal and spatial variability. Although there are many studies of benthic mineralization rates in estuarine systems, most are restricted to a limited salinity range (e.g. Hargrave \& Philips 1981, 1989, Hammond et al. 1985, Silverberg \& Sundby 1990, Therkildsen \& Lomstein 1993) or have an incomplete seasonal coverage (Boynton \& Kemp 1985. Burdige 1991). Notable exceptions are the studies of

\footnotetext{
•E-mail: jack.middelburg@nioo.nl

- Present address: Dutch Geological Survey, Richard Holkade 10, 2033 PZ Haarlem, The Netherlands
}

sedimentary carbon mineralization rates in Norsminde Fjord, Denmark (Jørgensen \& Sørensen 1985), the White Oak River estuary, North Carolina, USA (Kelley et al. 1990), Chesapeake Bay, USA (Roden \& Tuttle 1993a, b), Tomales Bay, California, USA (Dollar et al. 1991, Chambers et al. 1994) and some Texas, USA, estuaries (Yoon \& Benner 1992, Zimmerman \& Benner 1994). In all these systems, rates of benthic carbon mineralization show pronounced seasonality according to temperature, while significant spatial variability is observed in the White Oak River estuary (Kelley et al. 1990), Chesapeake Bay (Roden \& Tuttle 1993a, b) and Galveston Bay, Texas (Zimmerman \& Benner 1994), but not in Norsminde Fjord (Jørgensen \& Sørensen 1985 ) or the Nueces and Guadalupe estuaries in Texas (Yoon \& Benner 1992).

Studies on benthic mineralization in estuarine ecosystems have been limited not only in terms of their temporal and spatial coverage, but also in terms of their habitat; i.e. subtidal versus intertidal. The majority of studies on benthic mineralization in estuaries 
report and discuss results for subtidal areas only (Heip et al. 1995), with the exception of those executed in the Bay of Fundy, Canada (Hargrave \& Phillips 1989), and Flax Pond, Long Island, USA (Mackin \& Swider 1989). Yet intertidal sediments cover large areas in meso- and macro-tidal estuaries, are an important site for the accumulation of sediments and associated organic matter, and are the type of sediments most often studied for their faunal composition (Heip et al. 1995).

In this paper we report results of a seasonal study of sedimentary organic carbon mineralization rates at 8 intertidal stations along the salinity gradient of the Westerschelde Estuary, The Netherlands. Mineralization rates are based on the inorganic carbon efflux and exhibit significant spatial and seasonal variability.

\section{MATERIAL AND METHODS}

Study site. The river Schelde, with a total length of $330 \mathrm{~km}$, flows through France, Belgium and The Netherlands before it flows into the North Sea (Fig. 1). The tidal amplitude varies from 2 to $5 \mathrm{~m}$, and tidal exchange (about $45000 \mathrm{~m}^{3} \mathrm{~s}^{-1}$ ) is more important than freshwater discharge ( 50 to $200 \mathrm{~m}^{3} \mathrm{~s}^{-1}$ ) in the estuary. Due to the tidal range, intertidal sediments are the primary site of benthic carbon mineralization and carbon burial in the Westerschelde Estuary (Soetaert \& Herman 1995). The Schelde is heavily polluted by the discharge of important cities, active industrial areas and intensive livestock farming. As a consequence, the estuary is a highly heterotrophic system with annual carbon losses ranging from 16 to more than $100 \mathrm{~mol} \mathrm{C}$ $\mathrm{m}^{-2}$ (Soetaert \& Herman 1995). In the tidal freshwater part of the estuary, mineralization results in suboxic to anoxic conditions in the water column.

Approach. Rates of organic matter mineralization can be estimated from: (1) the consumption of organic

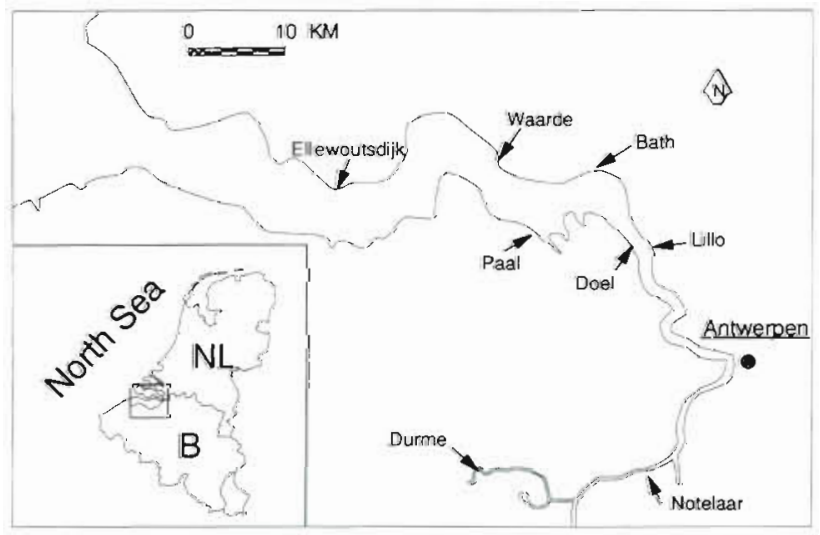

Fig. 1. Westerschelde Estuary (The Netherlands), showing sampling locations matter, (2) the consumption of oxidants and (3) the production of metabolites. Each of these 3 approaches may be based on experimental rate measurements or chemical gradients in combination with mass-balance considerations (Jørgensen 1983, Henrichs 1993, Middelburg et al. 1993). Carbon mineralization rates reported in this study were assessed using the third approach, namely the production of $\mathrm{CO}_{2}$ and $\mathrm{CH}_{4}$, the 2 major end-products of carbon mineralization. Intertidal sediments may release inorganic carbon $\left(\Sigma \mathrm{CO}_{2}\right.$, $\mathrm{CH}_{4}$ ) as dissolved $\mathrm{CO}_{2}, \mathrm{HCO}_{3}{ }^{-}, \mathrm{CO}_{3}{ }^{2-}$ and $\mathrm{CH}_{4}$ during inundation or as gaseous $\mathrm{CO}_{2}$ and $\mathrm{CH}_{4}$ during exposure. Organic carbon mineralization rates will be based on the release of gaseous carbon compounds during air exposure.

Sampling. In order to study the rate of sedimentary organic matter decomposition as a function of organic matter input and decomposition pathways, 8 representative intertidal tidal flat stations were selected (see Table 1). All stations were located high in the intertidal zone where sediments are exposed to air at least $1.4 \mathrm{~h}$ per day. Stations Durme and Notelaar are the tidal freshwater end-members of the estuary, stations Lillo and Doel represent the intermediate brackish part, stations Paal and Bath comprise the intermediate saline part and stations Waarde and Ellewoutsdijk are the saline end-members of the estuary (Fig. 1). Replicate measurements of carbon dioxide and methane fluxes were made monthly from September 1990 through December 1991 to provide information on organic matter decomposition rates along the estuarine gradient and seasonal variability. Flux measurements were made systematically at low tide and within a single week for each estuarine survey. Wooden walkboards were constructed and used to reduce disturbance caused by repeated visits and to reduce spatial variability. Results for Doel have been presented by Middelburg et al. (1995).

In order to determine short-term variability, additional measurements were made at the intermediate brackish station Lillo. Firstly, between June 5 and 25 . 1993, duplicate flux measurements were made each day to determine the daily variability of gaseous fluxes and its possible relation with the spring-neap tidal cycle. Secondly, on July 8, 1993, carbon dioxide and methane fluxes were determined starting immediately following air exposure until subsequent flooding. These data give information on the variability over an $8 \mathrm{~h}$ period of exposure.

Gaseous flux measurements. The release of carbon dioxide and methane was measured by monitoring accumulation of the gases beneath chambers placed over the sediment surface. The chambers had a $0.11 \mathrm{~m}^{2}$ base, a volume of $45 \mathrm{l}$ and were made of non-transparent polypropylene. During the Lillo semi-diurnal tide 
experiment a polypropylene base was installed to prevent any spatial variability and to reduce sediment disturbances during chamber flushing.

Carbon dioxide and methane concentrations were measured by circulating chamber air through Teflon tubes between the chamber and the gas monitor. Measurement with the multi-gas monitor used, a Brüel \& Kjaer type 1302, is based on the photoacoustic infrared detection method. Briefly, after thorough flushing of the Teflon tubes and analysis cell, the air sample is hermetically sealed in the analysis cell. The light emitted by a pulsating infra-red light source and purified by a narrow-band optical filter is selectively adsorbed. The temperature of the gas increases and decreases in response to the pulsating light transmitter, and this causes an equivalent increase and decrease in the pressure of the gas in the closed cell. Two ultrasensitive microphones mounted in the cell are used to measure this pressure wave, which is directly proportional to the concentration of the gas. Various gases can be measured in the same sample using different filters. A sequential measurement of carbon dioxide and methane takes about $90 \mathrm{~s}$. Detection limits for carbon dioxide and methane are 3 and 0.1 ppmv, respectively, and the response for both gases is linear up to several thousand ppmv. The reproducibilities at ambient levels are about 1 and $10 \%$, respectively. Fluxes were calculated by regression analysis from the recorded change in concentration over time, usually about $30 \mathrm{~min}$; regression slopes with a significance of $p>0.05$ were considered to be non-significant. Slopes with $p<0.01$ were usually obtained with minimum detectable fluxes of $0.13 \mathrm{mmol}$ $\mathrm{CH}_{4} \mathrm{~m}^{-2} \mathrm{~d}^{-1}$ and $3.3 \mathrm{mmol} \mathrm{CO} \mathrm{m}^{-2} \mathrm{~d}^{-1}$.

The results were also used to distinguish bubbling events from diffusive fluxes, since bubbling events may cause an abrupt shift in detector output (Fig. 2). Diffusive fluxes, either molecular or enhanced by bubble tubes, result in a continuous increase, whereas ebullition causes an episodic increase in methane concentrations. This partitioning approach has, however, a bubble detection resolution between about 2 and $30 \mathrm{~min}$, which is determined by the measurement frequency and duration respectively. Very high bubbling frequencies $(<2 \mathrm{~min}$ ) will result in a semi-continuous rise in methane concentrations. Similarly, bubbling events may not be recorded during the measurement period if the bubbling frequency is too low.

Sediment. During each sampling period and at each station, the porosity, salinity and the organic carbon (C) and nitrogen (N) contents were determined at 3 or more depth intervals. Porosity was calculated from water contents (weight loss on drying at $105^{\circ} \mathrm{C}$ ) assuming a dry density of $2.55 \mathrm{~kg} \mathrm{dm}^{-3}$; salinity was calculated from the chlorinity determined by potentiometric titration with $\mathrm{AgNO}_{3}$. Sediment $\mathrm{C}$ and $\mathrm{N}$ contents were

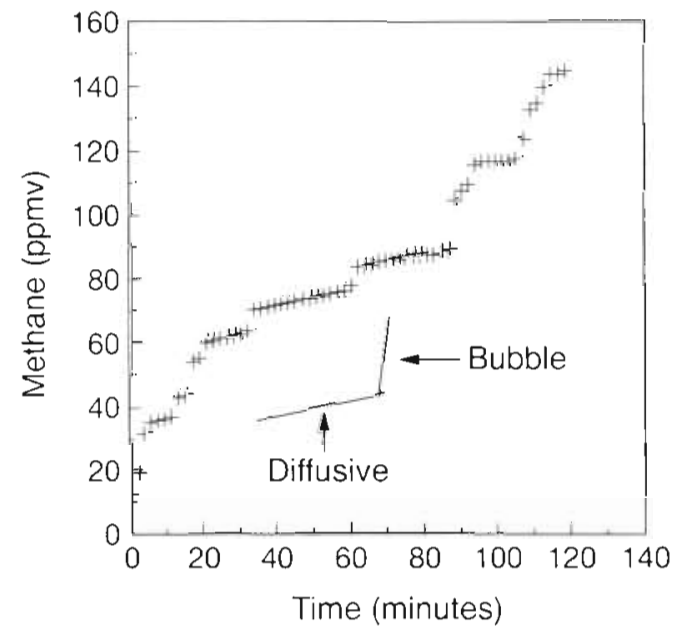

Fig. 2. Example of methane flux measurement. Diffusive fluxes are calculated by linear regression, and bubble fluxes by the difference Total - Diffusive = Bubble flux

determined using a Carlo-Erba $\mathrm{CN}$ analyzer following a recently developed in situ $\mathrm{HCl}$ acidification procedure (Nieuwenhuize et al. 1994).

Statistics. Annual flux estimates were calculated by integration of the curves connecting monthly averages of replicate measurements. Standard errors are based on the bootstrap technique, a nonparametric method (Efron 1979). All other standard deviations are based on a normal distribution and are combined errors using the square root of sum-of-squares technique for propagation of errors assuming independence of errors. Analysis of variance (ANOVA), based on log-transformed data, was used to evaluate significant differences between stations and the significance of seasonal, daily or hourly variability. Other statistical calculations were made following Sokal \& Rohlf (1995) using SYSTAT (Wilkinson 1990).

\section{RESULTS}

\section{Site characteristics}

Intertidal sediments in the Westerscheldt Estuary are generally dominated by silt, but vary from silty mud to fine sand. The muddy sediments at Durme had the highest porosity $(0.85)$, while the sandy sediments at Bath had the lowest porosity $(0.54$; Table 1$)$. Average pore-water salinity ranged from 0.8 psu at the tidal freshwater station Durme to 26.5 psu at the most saline station, Ellewoutsdijk (Table 1 ).

The organic carbon and nitrogen contents of the sediment varied from 1.4 to $4.6 \mathrm{wt} \%$ and 0.09 to $0.42 \mathrm{wt} \%$ $\mathrm{C}$ and $\mathrm{N}$, respectively; there was no gradient between 
0 and $40 \mathrm{~cm}$. Molar $\mathrm{C}: \mathrm{N}$ ratios range from 13.2 to 22.3 Sediments from the tidal freshwater stations had the highest $\mathrm{C}$ and $\mathrm{N}$ contents and lowest $\mathrm{C}: \mathrm{N}$ ratios. However, if concentrations were expressed on a volume basis rather than on a dry weight basis there were only minor differences between the stations (Table 1).

\section{Carbon dioxide and methane fluxes}

Fluxes of carbon dioxide and methane from the sediments to the atmosphere were highly variable, both in space and time, with a range of about 4 orders of magnitude (Fig. 3). Annual rates of carbon dioxide emission varied from about $8 \mathrm{~mol} \mathrm{C} \mathrm{m}^{-2}$ at Bath to about $137 \mathrm{~mol}$ $\mathrm{C} \mathrm{m}^{-2}$ at Durme (Table 2). Annual methane emission rates ranged from about $0.04 \mathrm{~mol} \mathrm{C} \mathrm{m}^{-2}$ at the saline stations Waarde and Ellewoutsdijk to about $200 \mathrm{~mol} \mathrm{C}$ $\mathrm{m}^{-2}$ at Durme. The total amount of carbon emitted annually varied from 8 to $339 \mathrm{~mol} \mathrm{C} \mathrm{m}^{-2} \mathrm{yr}^{-1}$. ANOVA analysis of the carbon dioxide and methane flux measurements indicated highly significant differences between stations $\left(\mathrm{CO}_{2}: \mathrm{n}=238, F=102, \mathrm{p}<0.0001, \mathrm{CH}_{4}: \mathrm{n}\right.$ $=189 ; F=141, p<0.0001)$ and seasons $\left(\mathrm{CO}_{2}: \mathrm{n}=238, F\right.$ =44.8, $\left.\mathrm{p}<0.0001, \mathrm{CH}_{4}: \mathrm{n}=189 ; F=5.1, \mathrm{p}<0.0001\right)$. Due to the unbalanced nature of the ANOVA analysis, it was not possible to determine interaction terms.

\section{Temperature}

In order to determine the temperature dependence of carbon fluxes, the emission rate data were fitted to the Arrhenius equation:

$$
\text { Rate of emission }=A \exp \left(-E_{a} / R T\right) \text {, }
$$

where $A$ is a pre-exponential factor; $E_{\mathrm{a}}$ is the apparent activation energy $\left(\mathrm{kJ} \mathrm{mol}^{-1}\right), R$ is the gas constant $\left(8.314 \times 10^{-3} \mathrm{~kJ} \mathrm{~mol}^{-1} \mathrm{~K}^{-1}\right)$ and $T$ is the absolute temperature $(\mathrm{K})$. Temperature varied annually between 2 and $22^{\circ} \mathrm{C}$. Apparent activation energies and $Q_{10}$ values for carbon dioxide and total carbon release varied from about 55 to $125 \mathrm{~kJ} \mathrm{~mol}^{-1}$ and 2.2 to 6.3 , respectively (Table 3 ). The rate of methane emission was not significantly related to temperature $(p>0.05)$.

\section{Temporal variability in gaseous carbon fluxes}

Daily carbon dioxide fluxes at Lillo varied from 17.5 to $227 \mathrm{mmol} \mathrm{C} \mathrm{m} \mathrm{m}^{-2} \mathrm{~d}^{-1}$ and averaged $120 \pm 9 \mathrm{mmol} \mathrm{C}$ $\mathrm{m}^{-2} \mathrm{~d}^{-1}$ (Fig. 4). Methane emission rates ranged from less than 0.14 to $189 \mathrm{mmol} \mathrm{C} \mathrm{m} \mathrm{C}^{-2} \mathrm{~d}^{-1}$, with a mean of $21.6 \pm 4.9 \mathrm{mmol} \mathrm{C} \mathrm{m}^{-2} \mathrm{~d}^{-1}$. ANOVA results indicated that differences existed between days for carbon dioxide $(\mathrm{n}=39, F=2.015, \mathrm{p}=0.039)$ and methane $(\mathrm{n}=33$,

Table 1 Description of sampling sites in the Westerschelde Estuary. Values are means \pm SD. POC: particulate organic carbon; TN: total nitrogen

\begin{tabular}{|c|c|c|c|c|c|c|}
\hline Station & $\begin{array}{l}\text { Salinity } \\
\text { (psu) }\end{array}$ & Porosity & $\begin{array}{l}\text { POC } \\
\text { (wt \%) }\end{array}$ & $\begin{array}{c}\mathrm{TN} \\
(w t \%)\end{array}$ & $\begin{array}{c}\text { Molar } \mathrm{C} / \mathrm{N} \\
\text { ratio }\end{array}$ & $\begin{array}{c}\text { POC } \\
(\mathrm{mmol} \mathrm{cm}-3)\end{array}$ \\
\hline Durme & $0.8 \pm 0.4$ & $0.85 \pm 0.03$ & $4.6 \pm 0.3$ & $0.42 \pm 0.07$ & $13.2 \pm 1.3$ & $15 \pm 0.1$ \\
\hline Notelaar & $1.6 \pm 0.8$ & $0.78 \pm 0.06$ & $3.1 \pm 0.6$ & $0.24 \pm 0.06$ & $14.7 \pm 1.0$ & $1.4 \pm 0.3$ \\
\hline Lillo & $10.2 \pm 1.9$ & $0.65 \pm 0.04$ & $2.4 \pm 0.3$ & $0.16 \pm 0.01$ & $16.5 \pm 1.7$ & $1.8 \pm 0.2$ \\
\hline Doel & $11.4 \pm 2.6$ & $0.74 \pm 0.08$ & $2.6 \pm 0.5$ & $0.18 \pm 0.02$ & $16.8 \pm 2.9$ & $1.4 \pm 0.3$ \\
\hline Paal & $15.7 \pm 3.3$ & $0.62 \pm 0.06$ & $1.7 \pm 0.3$ & $0.12 \pm 0.01$ & $18.0 \pm 3.7$ & $1.4 \pm 0.3$ \\
\hline Bath & $14.3 \pm 2.7$ & $0.54 \pm 0.07$ & $1.5 \pm 0.5$ & $0.11 \pm 0.04$ & $15.4 \pm 1.1$ & $1.5 \pm 0.5$ \\
\hline Waarde & $15.8 \pm 3.4$ & $0.63 \pm 0.07$ & $1.4 \pm 0.4$ & $0.09 \pm 0.03$ & $18.3 \pm 4.2$ & $1.1 \pm 0.3$ \\
\hline Ellewoutsdijk & $26.5 \pm 3.6$ & $0.61 \pm 0.09$ & $1.9 \pm 0.4$ & $0.09 \pm 0.04$ & $22.3 \pm 6.4$ & $1.6 \pm 0.4$ \\
\hline
\end{tabular}

Table 2. Annual carbon fluxes $\left(\mathrm{mol} \mathrm{C} \mathrm{m}^{-2} \mathrm{yr}^{-1}\right)$ at the stations in the Westerschelde Estuary. Integr.: Integrated fluxes

\begin{tabular}{|c|c|c|c|c|c|c|c|}
\hline Station & \multicolumn{2}{|c|}{$\mathrm{CO}_{2}$} & \multicolumn{2}{|c|}{$\mathrm{CH}_{A}$} & $\begin{array}{l}\text { C-f } \\
\text { Integr. }\end{array}$ & C-flux & $\begin{array}{l}\text { Max. contribution of } \\
\text { methanogenesis }(\%)\end{array}$ \\
\hline Durme & 137 & 20.7 & 202 & 16.9 & 339 & 26.7 & 100 \\
\hline Notelaar & 57.1. & 7.9 & 69.8 & 10.0 & 127 & 12.7 & 100 \\
\hline Lillo & 19.3 & 3.4 & 8.3 & 3.5 & 27.6 & 4.9 & 60 \\
\hline Doel & 18.6 & 2.9 & 2.55 & 1.15 & 21.2 & 3.1 & 24 \\
\hline Paal & 9.8 & 2.4 & 0.11 & 0.05 & 9.9 & 2.4 & 2.1 \\
\hline Bath & 7.9 & 1.7 & 0.14 & 0.05 & 8.0 & 1.7 & 3.5 \\
\hline Waarde & 16.4 & 2.9 & 0.04 & 0.03 & 16.5 & 2.9 & 0.5 \\
\hline Ellewoutsdijk & 17.8 & 3.3 & 0.05 & 005 & 17.8 & 3.3 & 0.6 \\
\hline
\end{tabular}



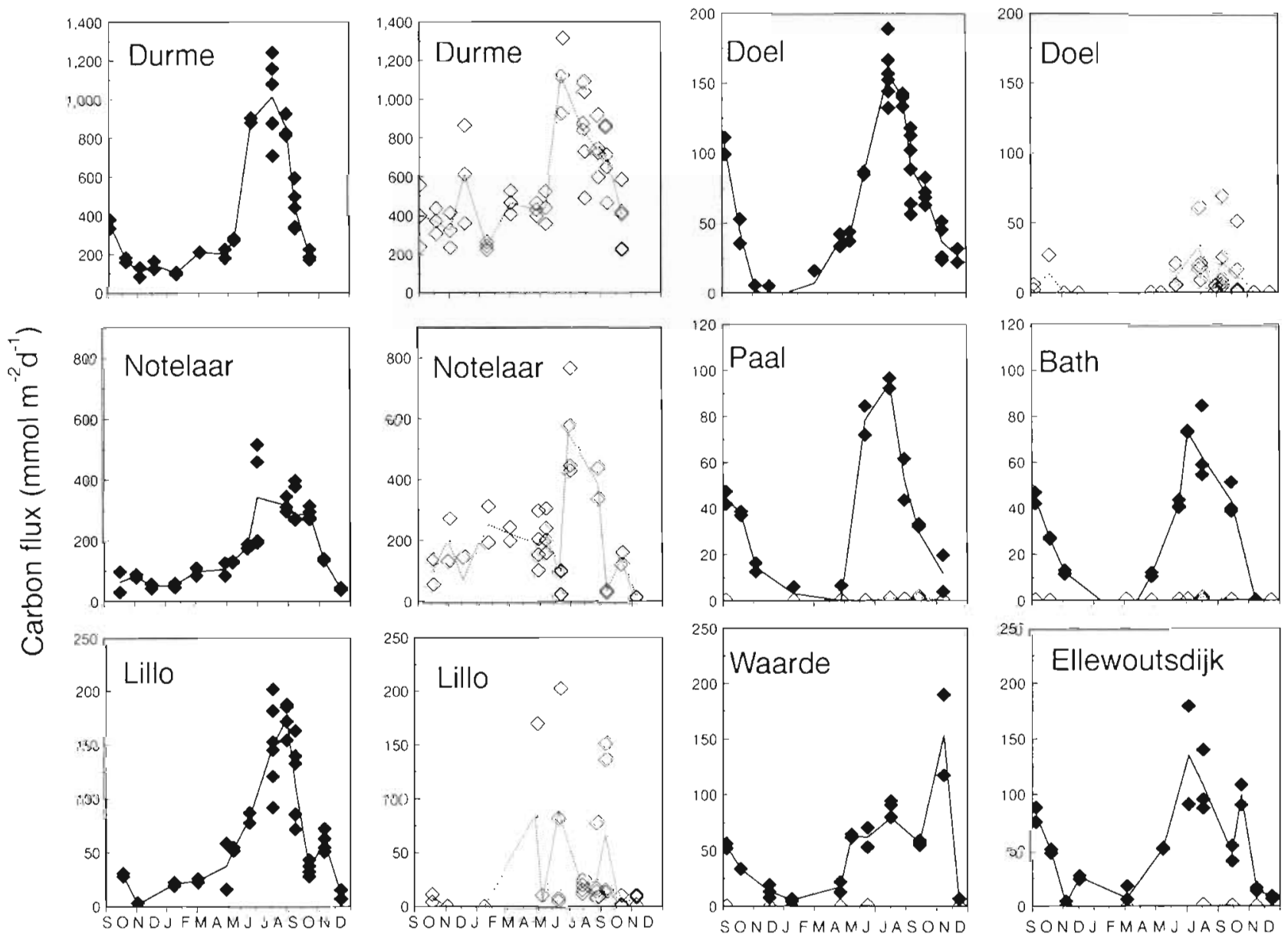

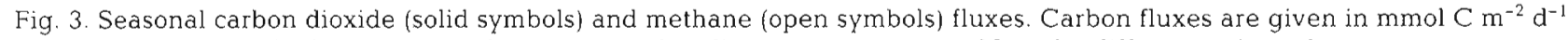
The lines connect the averages of replicate measurements. Note the differences in scale

$F=2.359, p=0.048$ ) release. An autocorrelation test ( $r=0.39$ for carbon dioxide and $r=0.04$ for methane)

Table 3. Seasonality of carbon dioxide fluxes and mineralization rates at sampling sites in the Westerschelde Estuary. Apparent activation energies $\left(E_{\mathrm{a}}\right)$ and their standard errors (SE) were obtained by linear regression of the logarithm of the rate versus $1 / T$, where $T=$ temperature; $Q_{10}$ values were derived by relating the rate to temperature using an exponential equation

\begin{tabular}{|c|c|c|c|c|c|c|}
\hline \multirow{3}{*}{$\begin{array}{l}\text { Station } \\
\text { Durme }\end{array}$} & \multicolumn{3}{|c|}{$\mathrm{CO}_{2}$} & \multicolumn{3}{|c|}{ C-flux } \\
\hline & \multicolumn{2}{|c|}{$\begin{array}{cc}E_{\mathrm{a}} & S E \\
(\mathrm{~kJ} \mathrm{~mol} & \left.\mathrm{mol}^{-1}\right)\end{array}$} & \multirow{2}{*}{$\begin{array}{l}Q_{10} \\
3.6\end{array}$} & \multicolumn{2}{|c|}{$\begin{array}{cc}E_{\mathrm{a}} & S E \\
\left(\mathrm{~kJ} \mathrm{~mol}^{-1}\right)\end{array}$} & $Q_{10}$ \\
\hline & 86 & 16 & & 54 & 14 & $2 . \overline{2}$ \\
\hline Notelaar & 76 & 11 & 3.0 & 56 & 20 & 2.3 \\
\hline Lillo & 99 & 31 & 4.3 & 102 & 35 & 4.6 \\
\hline Doel & 102 & 33 & 4.6 & 109 & 33 & 5.1 \\
\hline Paal & 115 & 21 & 5.3 & 116 & 21 & 5.4 \\
\hline Bath & 97 & 11 & 4.1 & 98 & 10 & 4.1 \\
\hline Waarde & 125 & 32 & 6.3 & 122 & 31 & 6.0 \\
\hline Ellewoutsdijk & 121 & 30 & 5.9 & 121 & 30 & 5.9 \\
\hline
\end{tabular}

and a non-parametric runs test with a significance worse than $10 \%$ showed that there was no relation between gaseous carbon fluxes and the neap-spring tidal cycle.

Carbon dioxide and methane fluxes during a single period of tidal exposure ranged from 56.4 to 121 and 3.8 to $129 \mathrm{mmol} \mathrm{C} \mathrm{m}^{-2} \mathrm{~d}^{-1}$, and averaged $86.3 \pm 5.2$ and $45.2 \pm 13.2 \mathrm{mmol} \mathrm{C} \mathrm{m}{ }^{-2} \mathrm{~d}^{-1}$, respectively (Fig. 5). Carbon dioxide emission rates were not significantly affected by the time of measurement ( $\mathrm{n}=11, F=1.7$, $\mathrm{p}=0.29$ ), whereas the methane flux was ( $\mathrm{n}=11, F=$ 7.1, $p=0.03$ ). A post-hoc Tukey-Kramer test indicated that the methane flux measured between 15:00 and 17:00 h differed from the fluxes measured during the first few hours ( $p=0.04$ ), but not from those measured at other times. This variability in methane emission at hourly time scales is due to the episodic nature of ebullition (e.g. see Fig. 2). Bubble escape rates were high immediately following exposure and just before inundation (Fig. 5). This may be related to the pressure release during falling tide (Chanton et al. 1989) or to a 


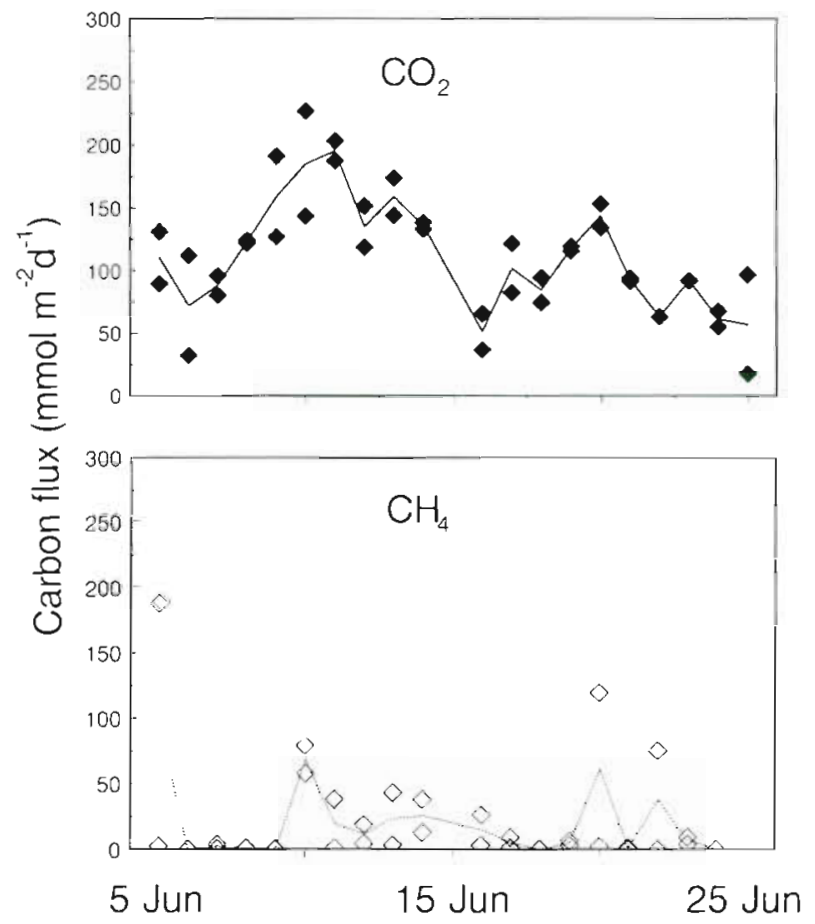

Fig. 4. Variability of carbon dioxide and methane fluxes during the Lillo experiment. Carbon fluxes are given in $\mathrm{mmol} \mathrm{C} \mathrm{m}^{-2}$ $\mathrm{d}^{-1}$. The line connects the averages of replicate measurements

pressure wave related to rising water levels. On the basis of abrupt increases in methane concentration during flux measurements, ebullition seemed to dominate overall fluxes of methane at Durme, Notelaar, Lillo and Doel. During bubbling events, individual methane release rates from ebullition ranged from less than $14 \mathrm{mmol} \mathrm{C} \mathrm{m} \mathrm{m}^{-2} \mathrm{~d}^{-1}$ up to about $275 \mathrm{~mol} \mathrm{C} \mathrm{m}^{-2} \mathrm{~d}^{-1}$.

Fig. 6 shows the seasonal cycle of carbon dioxide fluxes at Lillo for 1991, as well as more limited data that are available for 1990 and 1993. The agreement in carbon dioxide fluxes between these 3 years is good considering possible interannual differences in meteorological conditions, river discharge, etc. For comparison, we have also included depth-integrated rates of carbon dioxide production measured in 1991 and 1992 at Ballastplaat, a nearby intertidal flat (Panatrakul 1993). These depth-integrated carbon dioxide production rates are based on depth-integrated sulfate reduction rates obtained by whole core incubation with ${ }^{35} \mathrm{SO}_{4}$ and a stoichiometric factor of 2 $\left(2 \mathrm{CH}_{2} \mathrm{O}+\mathrm{SO}_{4}{ }^{2-} \rightarrow \mathrm{H}_{2} \mathrm{~S}+2 \mathrm{HCO}_{3}{ }^{-}\right)$. The excellent agreement between measured carbon dioxide emission rates at Lillo and carbon dioxide production rates based on sulfate reduction at Ballastplaat has 2 major implications. Firstly, this similarity reinforces the interannual reproducibility of seasonal patterns. Secondly, the strong agreement implies that carbon diox-

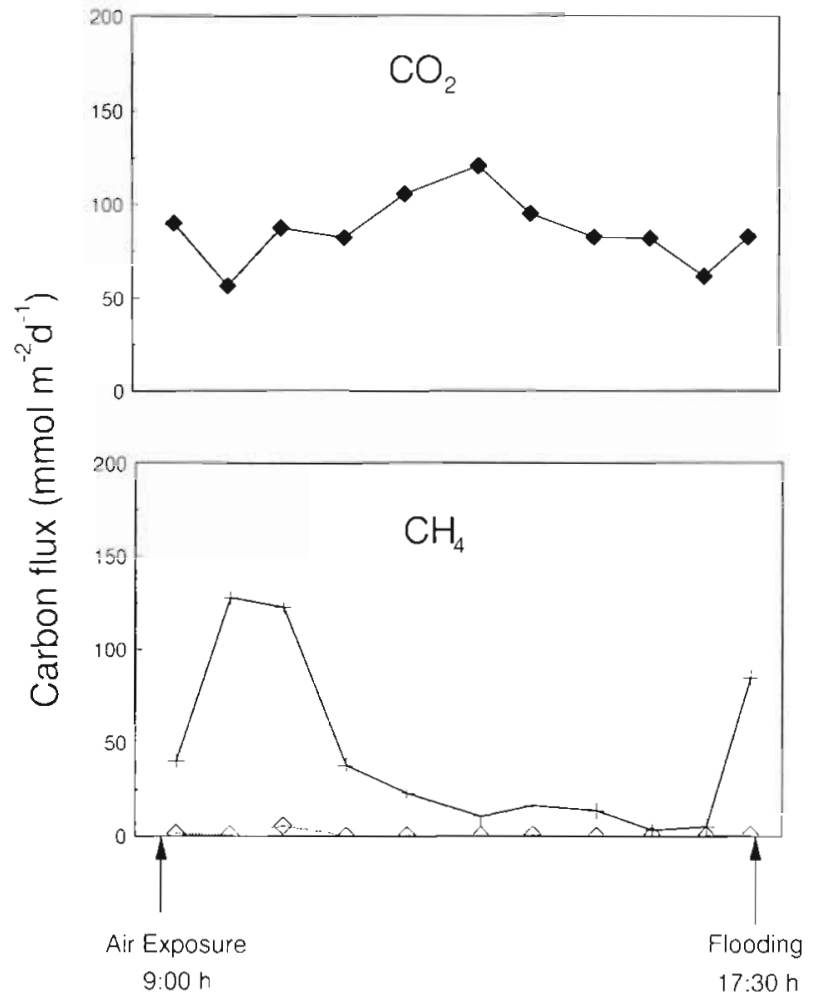

Fig. 5. Variability of carbon dioxide and methane fluxes during tidal exposure at Lillo (brackish zone). All fluxes are given in mmol $\mathrm{C} \mathrm{m}^{-2} \mathrm{~d}^{-1}$ Upper graph: carbon dioxide; lower graph: diffusive methane flux $(\diamond)$ and bubble flux $(+)$

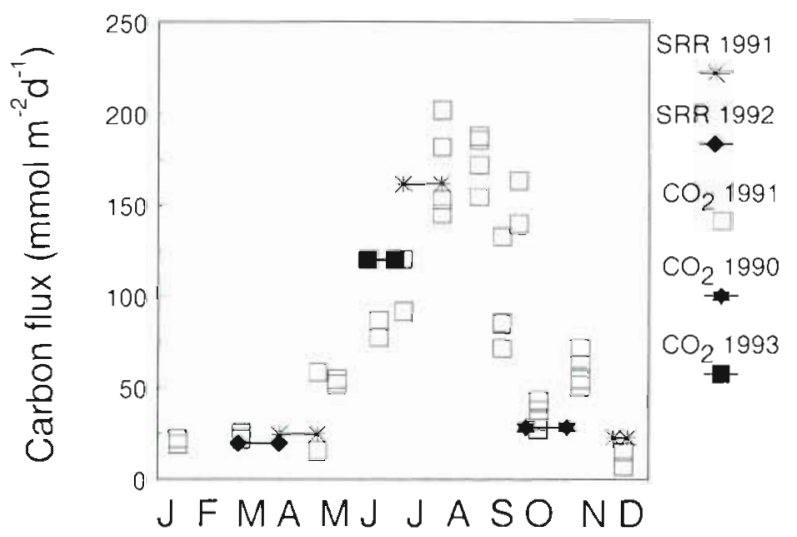

Fig. 6. Interannual reproducibility of mineralization rates at intertidal flats near Lillo. Carbon dioxide represents organic matter mineralization based on gaseous carbon dioxide measurements made at Lillo in different months in different years. SRR represents organic matter mineralization based on depth integrated sulfate reduction rates made at nearby Ballastplad (Panatrakul 1993). Lines indicate average value for that time period

ide fluxes measured at low tide provide a good measure of depth-integrated carbon dioxide production rates. 


\section{DISCUSSION}

In the absence of any oxidants, organic carbon mineralization through fermentative processes results in the production of equal amounts of carbon dioxide and methane according to:

$$
2 \mathrm{CH}_{2} \mathrm{O} \rightarrow \mathrm{CO}_{2}+\mathrm{CH}_{4}
$$

The availability of oxidants results in a proportionally greater amount of carbon dioxide relative to methane, either directly:

$$
\mathrm{CH}_{2} \mathrm{O}+\text { oxidant } \rightarrow \mathrm{CO}_{2}+\text { reaction products }
$$

or indirectly through oxidation of the methane formed by fermentation:

$$
\mathrm{CH}_{4}+\text { oxidant } \rightarrow \mathrm{CO}_{2}+\text { reaction products }
$$

Accordingly, the net production of carbon dioxide and methane integrates all metabolic processes involved in carbon mineralization since these 2 components are the ultimate reaction products.

If steady-state conditions apply to a sediment system, then the sum of all reactions in the sediment should be balanced by the flux out of the sediment, and the combined effluxes of carbon dioxide and methane provide a measure of organic matter mineralization rates. These estimates may, however, deviate from true mineralization rates if (1) there is assimilation of carbon dioxide by chemoautotrophs within the sediment or photoautotrophs at the sediment surface (Kelley et al. 1990, Chambers et al. 1994, Zimmerman \& Benner 1994), (2) there is significant dissolution or precipitation of carbonate minerals (Aller 1982, Anderson et al. 1986, McNichol et al. 1988, Green et al. 1993, Heip et al. 1995), and (3) steady-state conditions do not apply. Assimilation of carbon dioxide by (chemo) autotrophs can usually be neglected on seasonal time scales and is assumed not to be quantitatively important (Zimmerman \& Benner 1994). Assimilation of carbon dioxide by microphytobenthos or other photoautotrophs was not possible in our study because measurements were made in the dark. It is not easy to correct our data for carbonate reactions because there may be dissolution reactions in the surface layer and precipitation reactions in the deeper layers of the same sediment (e.g. Aller 1982, Anderson et al. 1986). For Long Island Sound sediments, Green et al. (1993) reported a mean net calcium carbonate dissolution rate of about $5.5 \mathrm{mmol} \mathrm{C} \mathrm{m} \mathrm{m}^{-2} \mathrm{~d}^{-1}$, with seasonal rates varying from no net dissolution up to about $19 \mathrm{mmol} \mathrm{C}^{-2}$ $\mathrm{d}^{-1}$. However, other studies, including that of Mackin \& Swider (1989) with intertidal sediments in Flax Pond, Long Island Sound, have shown that carbonate dissolution/precipitation reactions do not contribute significantly to carbon fluxes.
Non-steady-state conditions may arise if production rates exceed emission rates and there is a build-up of $\Sigma \mathrm{CO}_{2}$ and methane in pore water, or vice versa if effluxes exceed production rates and pore-water inventories decrease. Under such transient conditions, inorganic carbon effluxes will only reflect net production rates if corrections are applied for storage changes (Middelburg et al. 1995). This uncoupling between emission and production rates is more important for methane than for carbon dioxide. Carbon dioxide is relatively soluble in water and any increase/decrease in production rates will result in both higher/lower pore-water inventories and higher/lower emission rates, the net result being a slight delay of carbon dioxide emission rates relative to production rates (Middelburg et al. 1995). Due to the low solubility of methane, pore-water concentrations of methane may exceed the solubility limit and gas bubbles are formed upon continuing production of methane. These gas bubbles are released when hydrostatic pressures decrease during falling tide (Chanton et al. 1989). Data from the Lillo $8 \mathrm{~h}$ exposure experiment are consistent with this bubble release mechanism, though the significance is rather low (Fig. 5). Since our flux measurements were made at low tide, we may have overestimated the flux of methane at stations where ebullition occurs, i.e. at Durme, Notelaar, Doel and Lillo.

Although our carbon dioxide fluxes were measured over a period of $30 \mathrm{~min}$ and at low tide only, they are representative for long term carbon dioxide release. Firstly, carbon dioxide emission rates were not significantly affected by the time of measurement during the 8 h Lillo tidal exposure experiments (Fig. 5). Secondly, carbon dioxide fluxes measured at low tide at Doel are consistent with carbon dioxide production estimates based on $\Sigma \mathrm{CO}_{2}$ pore-water profiles (Middelburg et al. 1995), which have characteristic time scales of weeks rather than hours. Thirdly, carbon mineralization rates based on flux measurements at Doel and Lillo are very similar to carbon dioxide production rates based on sulfate reduction at the nearby Ballasplaat (Panatrakul 1993). By incubating whole cores with ${ }^{35} \mathrm{SO}_{4}$ for $5 \mathrm{~h}$. Panatrakul obtained depth-integrated rates of 24.8 , 162 and $22 \mathrm{mmol} \mathrm{C} \mathrm{m}^{-2} \mathrm{~d}^{-1}$ in April, July and December 1991, respectively. These carbon dioxide production rates correspond closely with those based on carbon dioxide fluxes at Doel $\left(37.6,157,26.7 \mathrm{mmol} \mathrm{C} \mathrm{m}{ }^{-2}\right.$ $\mathrm{d}^{-1}$, respectively) and Lillo $\left(37.1,149,11.2 \mathrm{mmol} \mathrm{C} \mathrm{m}{ }^{-2}\right.$ $\mathrm{d}^{-1}$, respectively; Fig. 6). Moreover, annual carbon mineralization rates at Ballasplaat based on sulfate reduction (18.8 mol C m $\mathrm{C}^{-2} \mathrm{yr}^{-1}$; Panatrakul 1993) are very similar to those based on extrapolation of shortterm carbon dioxide flux measurements made during air exposure at Lillo $\left(19.3 \pm 3.4 \mathrm{~mol} \mathrm{C} \mathrm{m}^{-2} \mathrm{yr}^{-1}\right)$ and Doel $\left(18.6 \pm 2.9 \mathrm{~mol} \mathrm{C} \mathrm{m} \mathrm{Cr}^{-1}\right)$. 
Being aware of these restrictions on the applicability of emission rates as a measure of total mineralization rates, we will assess the relative importance of fermentative and oxidative pathways of organic matter mineralization. At the most saline stations, Paal, Bath, Waarde and Ellewoutsdijk, organic matter mineralization occurred through oxidative pathways (>97\%), and methane fluxes can be neglected in carbon budgets (Table 2). Fermentative pathways could potentially account for all mineralization at Durme and Notelaar, for about $60 \%$ at Lillo and about for $24 \%$ at Doel (Table 2). Although these numbers probably are overestimates due to the tendency of methane to escape at low tide, they do indicate that fermentative pathways are important in freshwater and brackish-estuarine sediments. Sulfate availability, and hence salinity, has been reported to be the primary factor determining the relative importance of methanogenesis versus sulfate reduction in organic carbon mineralization in estuarine sediments (Bartlett et al. 1987, Capone \& Kiene 1988, Kelley et al. 1990, Heip et al. 1995).

\section{Effect of temperature on benthic mineralization rates}

The temperature dependence of benthic mineralization is usually observed to be exponential and is modelled using an integrated form of an Arrhenius-type equation (Vosjan 1974, Aller \& Yingst 1980, Westrich \& Berner 1988, this study). It should, however, be realized that the Arrhenius reaction rate law relates the reaction rate constant $(k)$, not the rate, to the activation energy and temperature. Moreover, the Arrhenius equation has been derived for well-defined chemical or enzymatic reactions for which the activation energy is constant by definition (Stumm \& Morgan 1981). Organic carbon mineralization involves the activity of a variety of microbial populations consisting of hydrolyzing, fermenting, acetogenic and respiring bacteria on a complex mixture of organic compounds. Hence, the activation energy estimated with Eq. (1) is an apparent activation energy, i.e. a measure of an ecological temperature response of the total microbial community, rather than an activation energy in the thermodynamical or biochemical sense (Westrich \& Berner 1988). There is no theoretical reason for apparent activation energies of benthic mineralization to be constant (Tarutis 1992) since the processes involved may shift with time, temperature, oxidant availability and reaction progress.

Apparent activation energies for benthic mineralization reported in the literature vary from 23 to $132 \mathrm{~kJ}$ $\mathrm{mol}^{-1}$ (Westrich \& Berner 1988), with most values clustering in the ranges from 50 to $60 \mathrm{~kJ} \mathrm{~mol}^{-1}\left(Q_{10} 2.1\right.$ to 2.4 ; Kelly \& Chynoweth 1981, Jargensen \& Sørensen
1985, Hargrave \& Phillips 1989, Therkildsen \& Lomstein 1993) and from 70 to $90 \mathrm{~kJ} \mathrm{~mol}{ }^{-1}\left(Q_{10} 2.8\right.$ to 3.7 ; Vosjan 1974, Aller \& Yingst 1980, Westrich \& Berner 1988, Klump \& Martens 1989, Mackin \& Swider 1989, Swider \& Mackin 1989, Roden \& Tuttle 1993a). Similarly, values of $E_{\mathrm{a}}$ obtained in this study varied from 54 to $125 \mathrm{~kJ} \mathrm{~mol}^{-1}$ (Table 3 ). This range of values suggests that the temperature dependence of benthic mineralization rates is highly variable and may depend on the substrate and processes involved.

Direct evidence for variable apparent activation energies has been reported by Crill \& Martens (1987) and Westrich \& Berner (1988). In Cape Lookout Bight (North Carolina, USA) sediment, the apparent $E_{\mathrm{a}}$ for depth integrated sulfate reduction rates is $114 \mathrm{~kJ}$ $\mathrm{mol}^{-1}$ in the summer and $23 \mathrm{~kJ} \mathrm{~mol}^{-1}$ in winter. Crill \& Martens (1987) attributed this change in $E_{a}$ to a change in the reaction mechanism between summer and winter. On the basis of laboratory experiments and field measurements in Long Island Sound, Westrich \& Berner (1988) showed that the temperature dependence for sulfate reduction increases as the overall rate of mineralization decreases. Moreover, these authors observed a higher temperature dependence for sulfate reduction rates with increasing depth in sediments, which they attributed to decreases in mineralization rate and rate constants of the organic matter with depth.

In Fig. 7, the apparent activation energy of organic carbon mineralization in the Westerschelde Estuary is plotted versus the annual rate of organic matter mineralization. For comparison the data reported by Westrich \& Berner (1988) are included as well. For both Westerschelde and Long Island Sound sediments, there seem to be fair correlations $(r=0.88$ and 0.78 , respectively) between apparent $E_{\mathrm{a}}$ values and depth integrated rates of mineralization. This relation for the Westerschelde also holds if only carbon dioxide production is considered, though the correlation coefficient is somewhat lower $(r=0.63)$.

Interpretation of these trends is not straightforward. Methodological artifacts can not be excluded, but are unlikely since the Westerschelde trend is based on field measurements of carbon dioxide production, whereas the data from Long Island Sound are based mainly on ${ }^{35} \mathrm{~S}$ sulfate reduction rated measured in the laboratory, but with some field measurements included. The trend observed for Westerschelde sediments might be explained by invoking a very tight coupling between temperature and local organic matter input at the more saline stations with relatively high rates of net primary production (Soetaert et al. 1994, Kromkamp \& Peene 1995) and low mineralization rates, and no or limited coupling between temperature and organic matter input at stations with high mineral- 


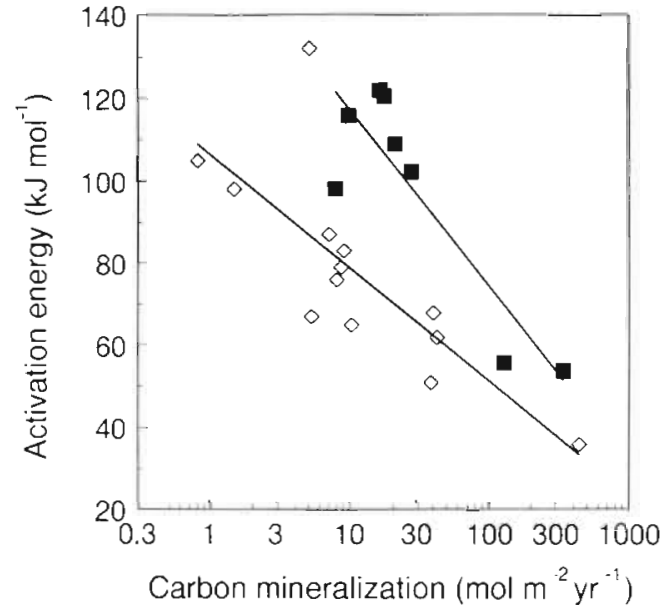

Fig. 7 Activation energy $\left(\mathrm{kJ} \mathrm{mol}^{-1}\right)$ versus depth-integrated mineralization rates (mol $\mathrm{C} \mathrm{m}^{-2} \mathrm{yr}^{-1}$ ). Solid symbols: Westerschelde Estuary (this study); open symbols: Long Island

Sound data integrated to $1 \mathrm{~m}$ (Westrich \& Berner 1988)

ization rates. However, net primary production in the Westerschelde is very low and not significant in the carbon budget (Soetaert \& Herman 1995). Another possibility could be that the microbial populations at sites with high mineralization rates have a lower ability to respond to temperature changes than those at sites with lower mineralization rates. This mechanism could perhaps explain the laboratory experiments of Westrich \& Berner (1988), but not their or our field data, since microbial populations have ample time to develop and adapt on seasonal time scales. Autoinhibition at high mineralization rates due to the accumulation of metabolites could account for both the laboratory as well as the field data. Inhibition due to accumulation of sulfide can probably be excluded since dissolved sulfide concentrations are low in Long Island Sound sediments (Westrich \& Berner 1988) and the suspected inhibition in Westerschelde sediments is highest at the freshwater sites, where sulfate reduction is likely less important. Finally, Westrich \& Berner (1988) proposed that organic matter that is less susceptible to degradation might have a higher apparent activation energy for decomposition. This mechanism is consistent with the trends reported in Fig. 7. Whatever the cause of these trends may be, the use of a constant temperature correction factor (either $E_{\mathrm{a}}$ or $Q_{10}$ ) in modelling seasonal rates of benthic mineralization at regional scales may lead to inaccurate results.

\section{Spatial differences in mineralization rates}

Rates of organic matter mineralization exhibit significant spatial variability (Fig. 3) with mean rates varying from about $340 \mathrm{~mol} \mathrm{C} \mathrm{m} \mathrm{Cr}^{-1}$ at Durme to about $8 \mathrm{~mol} \mathrm{C} \mathrm{m}{ }^{-2} \mathrm{yr}^{-1}$ at Bath (Table 2). The rate of organic matter mineralization depends primarily on the quantity and quality of the organic matter available (Westrich \& Berner 1984, Middelburg 1989, Boudreau 1992). The quantity of the organic carbon, as usually expressed on a dry weight basis, decreases going downstream from the tidal freshwater stations to the marine stations (Fig. 8A). For ecological studies, it is more appropriate to express the amount of organic matter available for decomposition on a volume or area basis because this accounts for differences in water content/porosity. If the amount of organic carbon in the Westerschelde estuary is expressed on a volume (Table 1) or an area basis (Fig. 8A), there is no estuarine gradient. Accordingly, the variability in mineralization rates along the Westerschelde Estuary (Fig. 8B) must be due to spatial differences in the lability of organic matter.
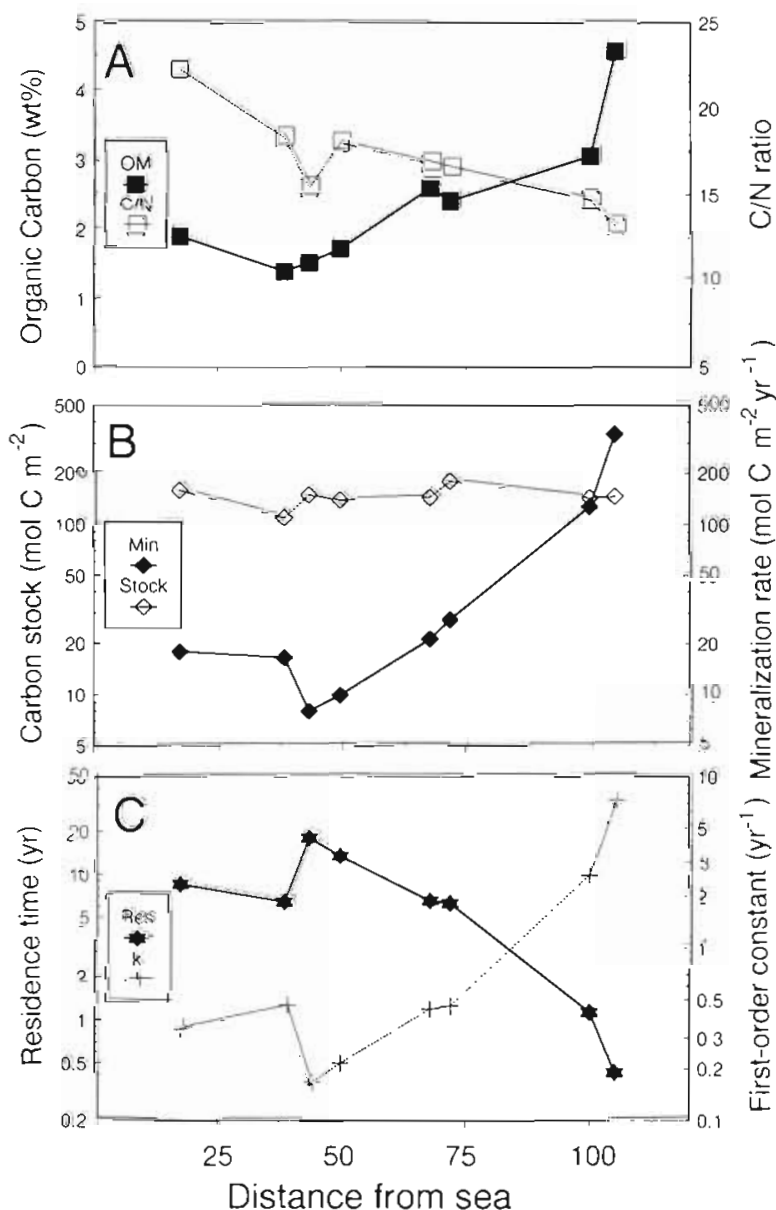

Fig. 8. Organic matter mineralization in intertidal sediments along the Westerschelde Estuary. (A) Organic carbon and molar $\mathrm{C} / \mathrm{N}$ ratio. (B) Organic carbon stock in the upper $10 \mathrm{~cm}$ and annual mineralization. (C) Organic carbon residence time in upper $10 \mathrm{~cm}$ of sediment and first-order rate constant 
The reactivity of organic matter is usually expressed in terms of a first-order rate constant (Berner 1980 , Hargrave \& Phillips 1981, 1989, Middelburg 1989):

$$
R=k C,
$$

where $R$ is the rate of organic matter mineralization, $C$ is the concentration of organic matter and $k$ is the first-order rate constant. For sediments receiving a certain amount of organic carbon, the residence time or the time to reach $95 \%$ of steady-state concentrations can be calculated according to (Hargrave \& Phillips 1981):

$$
\text { Residence time }=-\ln (0.05) / k=3 / k \text {. }
$$

Assuming steady-state on an annual basis, the residence time can also be obtained by dividing the organic carbon inventory in the upper $10 \mathrm{~cm}$ of the sediments with the depth-integrated mineralization rate. Organic carbon residence times in the upper $10 \mathrm{~cm}$ of intertidal Westerschelde sediments vary from 0.4 to $18.6 \mathrm{yr}$ (Fig 8C). First-order rate constant for bulk organic carbon in the upper $10 \mathrm{~cm}$ vary from 0.2 to $7 \mathrm{yr}^{-1}$ (Fig. 8C). Although the magnitudes of organic carbon residence times and first-order rate constants depend on the depth chosen, the relative differences in organic matter reactivities remain. Bulk organic matter in the upper $10 \mathrm{~cm}$ of intertidal sediment at Durme has an average first-order rate constant about 43 times that at Bath. The range, as well as the magnitude, of firstorder decay constants in surficial Westerschelde sediments is similar to those observed in surficial sediments of Chesapeake Bay (0.2 to $1.4 .6 \mathrm{yr}^{-1}$; Burdige 1991), Long Island Sound (0.8 to $8.8 \mathrm{yr}^{-1}$; Westrich \& Bermer 1984), Buzzards Bay, Massachusetts, USA (0.1 to $4.8 \mathrm{yr}^{-1}$; McNichol et al. 1988), Cape Lookout Bight (0.7 to $11.2 \mathrm{yr}^{-1}$; Martens \& Klump 1984) and the eastern Passage, Nova Scotia, Canada (0.2 to $2.1 \mathrm{yr}^{-1}$; Hargrave \& Phillips 1981), and in suspended matter of the upper Bay of Fundy $\left(0.3\right.$ to $5 \mathrm{yr}^{-1}$; Hargrave \& Phillips 1989).

The quality of organic matter, as expressed by its first-order decay constant, decreases upon mineralization because the more labile substrates are consumed first, with the remaining substrate consequently being more refractory (Westrich \& Berner 1984). This ageing effect has been observed in several environments covering various time scales (Middelburg 1989). The spatial distributions of mineralization rates and firstorder decay constants shown in Fig. 8 are consistent with input of allochthonous organic matter from both the river and sea, and subsequent ageing of this organic matter. A recent carbon budget study of Soetaert \& Herman (1995) indicated that each year about 104000 t $\mathrm{C}$ are imported, about $19000 \mathrm{t} \mathrm{C}$ are prodiced by autotrophs within the estuary, about
117000 tonnes $\mathrm{C}$ are consumed and about $7000 \mathrm{t} \mathrm{C}$ are exported to the North Sea. Soetaert \& Herman (1995) also showed that a relatively small amount

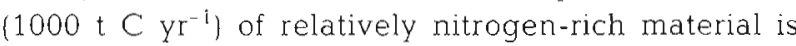
imported from the sea and that the majority of autochthonous carbon is produced in the marine part of the estuary.

The allochthonous organic matter entering the estuary from the river is very labile since it is composed of undegraded sewage sludge and dying freshwater algae and bacteria (Soetaert et al. 1994, Soetaert \& Herman 1995). While being transported downstream the organic matter undergoes decomposition and not is supplemented with fresh labile organic matter because autochthonous production is limited to the marine part (Soetaert \& Herman 1995, Soetaert et al. 1994). As a result, the overall lability of the organic matter decreases and both the mineralization rate and the first-order decay constant decrease (Fig. 8). In the marine part of the estuary, import of 'fresh' marine organic matter and local primary production result in a slight increase of labile organic matter and organic matter mineralization rates.

Finally, the annual carbon mineralization rates established in this study can be used to estimate the contribution of intertidal sediments to the total estuarine consumption of organic carbon $\left(117000 \mathrm{t} \mathrm{C} \mathrm{yr}^{-1}\right.$; Soetaert \& Herman 1995). Implicit in our approach is the assumption that mineralization rates measured in the upper intertidal zone can be considered representative of the entire intertidal zone. Rates of annual carbon mineralization rates in the compartments defined by Soetaert \& Herman (1995) were multiplied by the area of intertidal sediments in these compartments. The total amount of organic matter mineralized in intertidal sediments of the Westerschelde Estuary is about $16000 \mathrm{t} \mathrm{C} \mathrm{yr}^{-1}$, with about $50 \%$ of the mineralization occurring in the lower $50 \mathrm{~km}$ of the estuary. Our estimate for mineralization in intertidal sediments is very similar to that $\left(21000 \mathrm{t} \mathrm{C} \mathrm{yr}^{-1}\right)$ reported by Soetaert \& Herman (1995), partly because they have used the data reported in this study for their model calibration. Estimates for organic carbon burial rates in Westerschelde sediments are very scarce. Soetaert \& Herman (1995) reported an annual loss of $7000 \mathrm{t} \mathrm{C} \mathrm{yr}^{-1}$ and Middelburg et al. (1995) suggested a burial rate of $12500 \mathrm{t} \mathrm{C} \mathrm{yr}^{-1}$. On the basis of these estimates, intertidal sediments represent a net carbon sink of about 23000 to $29000 \mathrm{t} \mathrm{C} \mathrm{yr}^{-1}$, which is about 25 to $30 \%$ of the total estimated estuarine

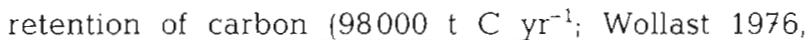
Soetaert \& Herman 1995). These very simple calculations provide first-order estimates only, but they do indicate that intertidal sediments are a significant component in estuarine ecosystems 
Acknowledgements. We thank R. Markusse for his help with sampling, Y Maas, P. van Bruegel, J. Sinke and A. Merks for laboratory assistance and Drs. K. Soetaert, P. Herman, M. Starink, M. Hemminga and C. Heip for critically reading the manuscript. Three anonymous reviewers are thanked for constructive comments. This is publication no. 2058 of the Netherlands Institute of Ecology, Yerseke.

\section{LITERATURE CITED}

Aller RC (1982) Carbonate dissolution in nearshore terrigeneous muds: the role of physical and biological reworking. J Geol 90:79-95

Aller RC, Yingst JY (1980) Relationships between microbial distributions and the anaerobic decomposition of organic matter in surface sediments of Long Island Sound, USA. Mar Biol 56:29-42

Anderson LG, Hall POJ, Iverfeldt A, Rutgers van der Loeff MML, Sundby B, Westerlund SFG (1986) Benthic respiration measured by total carbonate production. Limnol Oceanogr 31:319-329

Bartlett KB, Bartlett DS, Harriss RC, Sebacher Dl (1987) Methane emissions along a salt marsh salinity gradient. Biogeochemistry 4:183-202

Berner RA (1980) Early diagenesis: a theoretical approach. Princeton University Press, Princeton, NJ

Boudreau BP (1992) A kinetic model for microbic organicmatter decomposition in marine sediments. FEMS Microbiol Ecol 102:1-14

Boynton WR, Kemp WM (1985) Nutrient regeneration and oxygen consumption by sediments along an estuarine salinity gradient. Mar Ecol Prog Ser 23:45-55

Burdige DJ (1991) The kinetics of organic matter mineralization in anoxic marine sediments. J Mar Res 49:727-761

Capone DG, Kiene RP (1988) Comparison of microbial dynamics in marine and freshwater sediments: contrasts in anaerobic carbon metabolism. Limnol Oceanogr 33: $725-749$

Chambers RM, Hollibaugh JT, Vink SM (1994) Sulfate reduction and sediment metabolism in Tomales Bay, California. Biogeochemistry 25:1-18

Chanton JP, Martens CS. Kelley CA (1989) Gas transport from methane-saturated, tidal freshwater and wetland sediments. Limnol Oceanogr 34:807-819

Crill PM, Martens CS (1987) Biogeochemical cycling in an organic-rich coastal marine basin. 6 . Temporal and spatial variations in sulfate reduction rates. Geochim Cosmochim Acta 51:1175-1186

Dollar SJ, Smith SV, Vink SM, Obrebski S, Hollibaugh JT (1991) Annual cycle of benthic nutrient fluxes in Tomales Bay, California, and contribution of the benthos to total. ecosystem metabolism. Mar Ecol Prog Ser 79:115-125

Efron B (1979) Bootstrap methods: another look at the jackknife. Annuls Statist 7:1-26

Green MA Aller RC, Aller JY (1993) Carbonate dissolution and temporal abundance of Foraminifera in Long Island Sound sediments. Limnol Oceanogr 38:331-345

Hammond DE, Fuller C, Harmon D, Hartman B, Korosee M, Miller LG, Rea R, Warren S, Berelson W, Hager SW (1985) Benthic fluxes in San Francisco Bay. Hydrobiologia 129: $69-90$

Hargrave BT, Philips GA (1981) Annual in situ carbon dioxide and oxygen flux across a subtidal marine sediments. Estuar Coast Shelf Sci 12:725-737

Hargrave BT, Philips GA (1989) Decay times of organic carbon in sedimented detritus in a macrotidal estuary. Mar
Ecol Prog Ser 56:271-279

Heip CHR, Goosen NK, Herman PMJ, Kromkamp J, Middelburg JJ, Soetaert K (1995) Production and consumption of biological particles in temperate tidal estuaries. Oceanogr Mar Biol A Rev 33:1-149

Henrichs SM (1993) Early diagenesis of organic matter: the dynamics (rates) of cycling of organic compounds. In: Engel MH, Macko SA (eds) Organic geochemistry Plenum Press, New York, p 101-117

Jørgensen BB (1983) Processes at the sediment-water interface. In: Bolin B, Cook RB (eds) The major biogeochemical cycles and their interactions. SCOPE. J Wiley \& Sons, New York, p 477-515

Jørgensen BB, Sørensen J (1985) Seasonal cycles of $\mathrm{O}_{2}, \mathrm{NO}_{3}^{-}$, and $\mathrm{SO}_{4}{ }^{2-}$ reduction in estuarine sediments: the significance of a $\mathrm{NO}_{3}{ }^{-}$reduction maximum in spring. Mar Ecol Prog Ser 48:147-154

Kelley CA, Martens CS, Chanton JP (1990) Variations in sedimentary carbon remineralization rates in the White Oak River estuary, North Carolina. Limnol Oceanogr 35: $372-383$

Kelly CA, Chynoweth DP (1981) The contributions of temperature and of the input of organic matter in controlling rates of sediment methanogenesis. Limnol Oceanogr 26: 891-897

Klump JV, Martens CS (1989) The seasonality of nutrient regeneration in an organic-rich coastal sediment: kinetic modeling of changing pore-water nutrient and sulfate distributions. Limnol Oceanogr 34:559-577

Kromkamp J, Peene J (1995) Possibility of net phytoplankton primary production in the turbid Schelde Estuary (SW Netherlands). Mar Ecol Prog Ser 121:249-259

Mackin JE, Swider KT (1989) Organic matter decomposition pathways and oxygen consumption in coastal marine sediments. J Mar Res 47:681-716

Martens CS, Goldhaber MB (1978) Early diagenesis in transitional sedimentary environments of the White Oak River estuary, N.C. Limnol Oceanogr 23:428-441

Martens CS, Klump JV (1984) Biochemical cycling in an organic-rich coastal marine basin 4. An organic carbon budget for sediments dominated by sulfate reduction and methanogenesis. Geochim Cosmochim Acta 48:1987-2004

McNichol AP, Lee C, Druffel ERM (1988) Carbon cycling in coastal sediments: 1 . A quantitative estimate of remineralization of organic carbon in the sediments of Buzzards Bay, MA. Geochim Cosmochim Acta 52:1531-1543

Middelburg JJ (1989) A simple rate model for organic matter decomposition in marine sediments. Ceochim Cosmochim Acta 53:1577-1581

Middelburg JJ, Klaver G, Nieuwenhuize J, Vlug T (1995) Carbon and nitrogen cycling in intertidal sediments near Doel, Scheldt Estuary. Hydrobiologia 311:57-69

Middelburg JJ, Vlug T, van der Nat FJWA (1993) Organic matter mineralization in marine systems. Global Planet Change 8:47-58

Nieuwenhuize J, Maas YEM, Middelburg JJ (1994) Rapid analysis of organic carbon and nitrogen in particulate materials. Mar Chem 45:217-224

Panutrakul S (1993) Impact of sulfur cylce on the mobilization of heavy metals in intertidal flat's sediments. PhD thesis, Free University of Brussels

Roden EE, Tuttle JH (1993a) Inorganic sulfur cycling in mid and lower Chesapeake Bay sediments. Mar Ecol Prog Ser 93:101-118

Roden EE, Tuttle JH (1993b) Inorganic sulfur turnover in oligohaline estuarine sediments. Biogeochemistry 22: $81-105$ 
Silverberg N, Sundby B (1990) Sediment-water interaction and early diagenesis in the Laurentian Trough. In: ElSabh MI, Silverberg N (eds) Coastal and estuarine studies, Vol 39. Springer-Verlag, New York, p 202-238

Soetaert K, Herman PMJ (1995) Carbon flows in the Westerschelde estuary (The Netherlands) evaluated by means of a global ecosystem model (MOSES). Hydrobiologia 311. $247-266$

Soetaert $K_{1}$ Herman PMJ, Kromkamp J (1994) Living in the twilight: estimating net phytoplankton growth in the Westerschelde estuary (The Netherlands) by means of a global ecosystem model (MOSES). J Plankton Res 16: $1277-1301$

Sokal RR, Rohlf FJ (1995) Biometry, 3rd edn. WH Freeman and $\mathrm{Co}$, New York

Stumm W, Morgan JJ (1981) Aquatic chemistry. J Wiley \& Sons, New York

Swider KT, Mackin JE (1989) Transformations of sulfur in marsh-flat sediments. Geochim Cosmochim Acta 53: $2311-2323$

Tarutis WJ (1992) Temperature dependence of rate constants derived from the power model of organic matter decomposition. Geochim Cosmochim Acta 56:1387-1390

This article was submitted to the editor
Therkildsen MS, Lomstein BA (1993) Seasonal variation in net benthic $C$-mineralization in a shallow estuary. FEMS Microbıol Ecol 12:131-142

Vosjan JH (1974) Sulfate in water and sediment of the Dutch Wadden Sea. Neth J Sea Res 8:208-213

Westrich JT, Berner RA (1984) The role of sedimentary organic matter in bacterial sulfate reduction: the $\mathrm{G}$-model tested. Limnol Oceanogr 29:236-249

Westrich JT, Berner RA (1988) The effect of temperature on rates of sulfate reduction in marine sediments. Geomicrob J 6:99-117

Wilkinson L (1990) SYSTAT the system for statistics. Systat, Inc, Evanston, IL

Wollast R (1976) Transport et accumulation de pollutants dans l'estuaire de l'Escaut. In: Nihoul JC, Wollast R (eds) l'Estuaire de l'Escaut. Project Mer, Rapport final, Bruxelles, Service du Premier Ministre 10:191-201

Yoon WB, Benner R (1992) Denitrification and oxygen consumption in sediments of two south Texas estuaries. Mar Ecol Prog Ser 90:157-167

Zimmerman AR, Benner R (1994) Denitrification, nutrient regeneration and carbon mineralization in sediments of Galveston Bay, Texas, USA. Mar Ecol Prog Ser 114:275-288

Manuscript first received: June 7, 1995

Revised version accepted: September 19, 1995 